\title{
Oligomer and highly oxygenated organic molecule formation from oxidation of oxygenated monoterpenes emitted by California sage plants
}

\author{
Archit Mehra ${ }^{1}$, Jordan E. Krechmer ${ }^{2}$, Andrew Lambe ${ }^{2}$, Chinmoy Sarkar ${ }^{3}$, Leah Williams ${ }^{2}$, Farzaneh Khalaj ${ }^{4}$, \\ Alex Guenther ${ }^{3}$, John Jayne ${ }^{2}$, Hugh Coe ${ }^{1}$, Douglas Worsnop ${ }^{2}$, Celia Faiola ${ }^{4,5}$, and Manjula Canagaratna ${ }^{2}$ \\ ${ }^{1}$ Centre for Atmospheric Science, School of Earth and Environmental Sciences, \\ The University of Manchester, Manchester, UK \\ ${ }^{2}$ Center for Aerosol and Cloud Chemistry, Aerodyne Research Inc., Billerica, Massachusetts, USA \\ ${ }^{3}$ Department of Earth System Science, University of California Irvine, Irvine, California, USA \\ ${ }^{4}$ Department of Ecology and Evolutionary Biology, University of California, Irvine, Irvine, California, USA \\ ${ }^{5}$ Department of Chemistry, University of California, Irvine, Irvine, California, USA
}

Correspondence: Manjula Canagaratna (mrcana@aerodyne.com) and Hugh Coe (hugh.coe@ manchester.ac.uk)

Received: 21 March 2020 - Discussion started: 14 April 2020

Revised: 21 July 2020 - Accepted: 7 August 2020 - Published: 24 September 2020

\begin{abstract}
Plants emit a diverse range of biogenic volatile organic compounds (BVOCs) whose oxidation leads to secondary organic aerosol (SOA) formation. The majority of studies of biogenic SOA have focused on single or simple multicomponent BVOC mixtures thought to be representative of Northern hemispheric deciduous or mixed forest conditions. Gaps remain in our understanding of SOA formation from complex mixtures of real plant emissions in other environments.

Towards the goal of understanding SOA in other regions, we conducted the first comprehensive study of SOA from oxygenated monoterpenes. These are the dominant emissions from the most common plant species in southern California's coastal sage ecosystem: black sage (Salvia mellifera) and California sagebrush (Artemisia californica).

Emissions from sage plants, as well as single compounds representing their major emissions (camphor, camphene and eucalyptol), were oxidised in an Aerodyne potential aerosol mass oxidation flow reactor (PAM-OFR). The chemical composition of SOA was characterised using a high-resolution time-of-flight iodide-anion chemicalionisation mass spectrometer equipped with a Filter Inlet for Gases and AEROsols (FIGAERO-I-HR-ToF-CIMS) under low- and medium- $\mathrm{NO}_{x}$ conditions.
\end{abstract}

SOA from oxygenated monoterpenes showed a higherorder oligomer content and a greater presence of highly oxygenated organic molecules (HOMs) than non-oxygenated monoterpenes, with HOM contributing $27 \%-47 \%$ and $12 \%-14 \%$ of SOA product signal from oxygenated and nonoxygenated monoterpenes respectively. This study highlights the potential importance of oxygenated monoterpene emissions for SOA formation in woody shrub ecosystems.

\section{Introduction}

Secondary organic aerosol (SOA) formed from the oxidation of volatile organic compounds (VOCs) contributes $50 \%$ $85 \%$ of organic aerosol in the atmosphere (Jimenez et al., 2009). VOCs from biogenic emission sources (BVOCs) are estimated to contribute $75 \%-90 \%$ of the total VOCs (Guenther et al., 1995; Lamarque et al., 2010, Carlton et al., 2009; Claeys et al., 2004). BVOC oxidation by reaction with ozone, hydroxyl radical or nitrate radical has been estimated to contribute up to $50 \%$ of SOA worldwide (Chung and Seinfeld, 2002; Hoffmann et al., 1997) with implications for air quality, climate and human health (Chung and Seinfeld, 2002; Fiore et al., 2012; Forster et al., 2007; Lohmann and Feichter, 2005). 
The formation of highly oxygenated organic molecules (HOMs) has been identified as a pathway for new particle formation (NPF) and growth of SOA (Bianchi et al., 2019; Ehn et al., 2014). Recent work has shown that alongside HOM formation from ozonolysis (Quéléver et al., 2019), hydroxyl radical oxidation of monoterpenes is a large source of HOMs (Berndt et al., 2016). Oligomerisation is another key pathway to formation of SOA and has been identified as important for monoterpenes including $\alpha$-pinene and limonene (Hall and Johnston, 2011; Kourtchev et al., 2016; Kundu et al., 2012; Putman et al., 2011; Tolocka et al., 2004). Uncertainties remain in the relative importance and sensitivity to anthropogenic conditions of the different SOA formation pathways alongside their relevance in other BVOC systems.

Isoprene and $\alpha$-pinene are globally the most abundant aerosol-forming BVOCs emitted from vegetation and forests and, thus, have been the focus of many studies on SOA formation and composition (Carlton et al., 2009; Després et al., 2012; Guenther et al., 2012; Kroll, 2006; Zhang et al., 2015). However, these are only a subset of over 1700 BVOCs that have been identified from plant emissions (Dudareva et al., 2006). Although most of these are thought to have a negligible contribution on the global scale, they could be a major contributor in specific ecosystems and, therefore, important on local scales. Despite this diversity, the chemical composition of SOA from the majority of these BVOCs remains unknown. Real plant emissions are mixtures of many BVOCs, yet it remains unclear if the compounds currently used as proxies for BVOCs are adequate to describe the SOA chemistry of plants globally (Faiola et al., 2018).

Real plant emissions have been used as atmospherically relevant VOC mixtures in various studies (Faiola et al., 2015, 2019; Hao et al., 2009, 2011; Joutsensaari et al., 2005, 2015; Mentel et al., 2009; VanReken et al., 2006; Yli-Pirilä et al., 2016; Ylisirniö et al., 2020; Zhao et al., 2017); however, most of these studies used conifers or broad-leaved trees. Comparison of pine species has shown that thresholds of NPF from plant emissions are lower than that for $\alpha$-pinene alone, and plants with a larger proportion of oxygenated VOCs (OVOCs) have the lowest thresholds (Mentel et al., 2009). For mainly isoprene-emitting plants, SOA yields from co-emitted VOCs were lower than expected from singleVOC data, suggesting that isoprene inhibits SOA formation (Wyche et al., 2014). Furthermore, the recent incorporation of terpene complexity into a box model has demonstrated enhancements of 1.5-2.3 in SOA mass yields from Scots pine, relative to the commonly used model monoterpene $\alpha$ pinene (Faiola et al., 2018). Although studies of SOA from real plant emissions are limited, all results show pronounced differences between plants and single components. This suggests that the simplification of BVOC complexity may be responsible for model underestimates of organic aerosol mass loadings in dry shrubland areas of the western United States (Carlton et al., 2018).
The impact of mixing BVOCs on SOA has been recently studied using mixtures of $\alpha$-pinene and isoprene, and results have shown that isoprene can suppress the mass yield derived from monoterpenes through oxidant scavenging (McFiggans et al., 2019). Utilisation of detailed chemical composition enabled attribution of this effect to a reduction in the yield of low-volatility HOM products which form SOA, relative to their yields during single-VOC oxidation (McFiggans et al., 2019). This study demonstrates the utility of a detailed chemical composition for the deconvolution of SOA from complex mixtures. Despite these findings, studies to date have lacked an adequate characterisation of differences in the chemical composition between SOA from plants and single precursors.

Relative proportions of different BVOCs in the atmosphere are a function of both the plant species and environmental factors. Thus, VOC mixtures vary regionally and globally, making the need to understand SOA formation from different precursors and mixtures vital for application in regions with different BVOC source profiles (Guenther, 2013). For example, oxygenated monoterpene emissions and ambient concentrations were higher than anthropogenic and monoterpene VOCs in some agricultural locations in California (Gentner et al., 2014), suggesting that they may be important for SOA formation in this region.

In this study we investigate the VOC emission profile of two species of plant native to California - black sage (Salvia mellifera, referred to as "Sage" hereinafter) and California sagebrush (Artemisia californica, referred to as "Artemisia" hereinafter) - and subsequent SOA formation from hydroxyl radical oxidation of these VOCs in an oxidation flow reactor (OFR) under low- and medium- $\mathrm{NO}_{x}$ conditions. On the basis of the measured emission profiles of these species, we also studied SOA formed from individual VOCs that were major contributors, including camphene, camphor and eucalyptol (Table 1).

Although terpenoid emissions of sage plants into the atmosphere were reported in the mid-1970s (Tyson et al., 1974) and have been considered by plant scientists for their ecological function (Karban et al., 2014), this study provides the first detailed SOA composition measurements from these plants and is the first study of woody shrubs, which are the dominant vegetation type in many landscapes including coastal sage scrub, shrub lands and chaparral. Atmospherically relevant studies of the VOC precursors alone have focused on gas-phase reaction rates and chemistry but have not looked into the SOA (Ceacero-Vega et al., 2012; Gaona-Colmán et al., 2017). Our results show high HOM and oligomer formation from oxygenated monoterpenes, which dominate the emission profile of California sage plants. 
Table 1. Volatile organic compounds investigated in this study.

\begin{tabular}{|c|c|c|c|}
\hline Precursor & Formula & Structure & $\mathrm{kOH}\left(\mathrm{cm}^{3}\right.$ molec $\left.^{-1} \mathrm{~s}^{-1}\right)$ \\
\hline Camphene & $\mathrm{C}_{10} \mathrm{H}_{16}$ & & $\begin{array}{l}5.95 \times 10^{-11} \\
\text { (Gaona-Colmán et al., 2017) }\end{array}$ \\
\hline Camphor & $\mathrm{C}_{10} \mathrm{H}_{16} \mathrm{O}$ & & $\begin{array}{l}3.8 \times 10^{-12} \\
\text { (Ceacero-Vega et al., 2012) }\end{array}$ \\
\hline $\begin{array}{l}\text { Eucalyptol } \\
(1,8 \text {-cineole })\end{array}$ & $\mathrm{C}_{10} \mathrm{H}_{18} \mathrm{O}$ & & $\begin{array}{l}1.11 \times 10^{-11} \\
(\text { Corchnoy and Atkinson, 1990) }\end{array}$ \\
\hline
\end{tabular}

\section{Experimental methods}

\subsection{Oxidation of VOCs and SOA production}

SOA particles were generated by the $\mathrm{OH}$ oxidation of VOCs in an Aerodyne potential aerosol mass (PAM) oxidation flow reactor (OFR) (Lambe et al., 2011), affording short experimental timescales and the ability to generate consistent and reproducible oxidation conditions. Plant emissions were sampled from an external plant chamber into the OFR using an eductor. The plant enclosure was constructed from Teflon sheets and was approximately $114 \mathrm{~cm} \times 35 \mathrm{~cm} \times 35 \mathrm{~cm}$. Eucalyptol was injected into the OFR through a length of Teflon tubing using a syringe pump, prior to evaporation into $\mathrm{N}_{2}$ carrier gas. Camphene or camphor vapour was introduced by flowing $\mathrm{N}_{2}$ over solid camphene or camphor placed in a Teflon tube. In the OFR, $\mathrm{OH}, \mathrm{HO}_{2}$ and $\mathrm{NO}$ were generated via the following reactions:

$\mathrm{O}_{3}+h v_{254} \rightarrow \mathrm{O}\left({ }^{1} \mathrm{D}\right)+\mathrm{O}_{2}$

$\mathrm{O}\left({ }^{1} \mathrm{D}\right)+\mathrm{H}_{2} \mathrm{O} \rightarrow 2 \mathrm{OH}$

$\mathrm{O}\left({ }^{1} \mathrm{D}\right)+\mathrm{N}_{2} \mathrm{O} \rightarrow 2 \mathrm{NO}$

All experiments were carried out at room temperature (approximately $26^{\circ} \mathrm{C}$ ), a relative humidity of $35 \%$ and a constant gas flow of $10 \mathrm{slpm}$ (standard litres per minute) through the OFR, including the injection of $\sim 3 \% \mathrm{~N}_{2} \mathrm{O}$ at the inlet to generate $\mathrm{NO}$ in a subset of experiments (Lambe et al., 2017; Peng et al., 2018). The OFR was run in OFR254 mode which uses $254 \mathrm{~nm}$ photons to generate radicals by the reactions outlined above, and the estimated $\mathrm{OH}$ exposures under these conditions are outlined in 2.5. In experiments where $\mathrm{N}_{2} \mathrm{O}$ was added to the OFR, the $\mathrm{NO} / \mathrm{HO}_{2}$ ratio was approximately 0.5 , as calculated using an adapted version of the OFR photochemical box model described in Li et al. (2015) and Peng et al. (2015). Between experiments, the flow reactor was flushed with humidified synthetic air at full lamp power for $12-36 \mathrm{~h}$ until the particle mass generated was reduced to background concentrations $\left(<0.5 \mu \mathrm{g} \mathrm{m}^{-3}\right)$, as measured by a scanning mobility particle sizer (SMPS) and an aerosol mass spectrometer (AMS). Instrument and OFR backgrounds were determined using $\mathrm{N}_{2}+\mathrm{O}_{2}$ injection with lights off and on and with and without precursor injection. The results presented here are for low- $-\mathrm{NO}_{x}([\mathrm{NO}]<0.1 \mathrm{ppb})$ and medium- $\mathrm{NO}_{x}$ $\left([\mathrm{NO}]>1 \mathrm{ppb},[\mathrm{NO}]:\left[\mathrm{HO}_{2}\right]=0.5\right)$ conditions.

\subsection{FIGAERO-I-HR-ToF-CIMS Measurements}

A time-of-flight chemical ionisation mass spectrometer (Lee et al., 2014) using an iodide-anion ionisation system was coupled with a Filter Inlet for Gases and AEROsols (FIGAERO) (Lopez-Hilfiker et al., 2014) for detection of both gas- and particle-phase composition (referred to as I-CIMS hereinafter). The gas-phase inlet consisted of a piece of $0.5 \mathrm{~m}$ long $1 / 4^{\prime \prime}$ o.d. (outer diameter) PFA (perfluoroalkoxy) tubing from which the I-CIMS subsampled 2 slpm. The aerosolphase inlet consisted of $0.5 \mathrm{~m}$ stainless-steel tube through which $2 \mathrm{slpm}$ was pulled over a Teflon filter. The sample flow (gas or aerosol) entered an ion molecule reaction region (IMR) which was maintained at a pressure of $100 \mathrm{mbar}$ using a pump fitted with a pressure controller. $\mathrm{I}^{-}$reagent ion was made by flowing $\mathrm{N}_{2}$ over a permeation tube containing methyl iodide $\left(\mathrm{CH}_{3} \mathrm{I}\right)$, mixing that flow with a humidified $\mathrm{N}_{2}$ flow from a bubbler and then ionising with a Po-210 (polonium-210) source. Particle mass concentrations were monitored using a TSI scanning mobility particle sizer (SMPS, TSI, Model 3080), and the collection time on the FIGAERO filter was varied to ensure hundreds of nanograms of aerosol in each sample for the different precursors. The FIGAERO thermal desorption cycle consisted of a $15 \mathrm{~min}$ temperature ramp to $200^{\circ} \mathrm{C}$, a hold at that temperature for $10 \mathrm{~min}$ and then cooling down over $15 \mathrm{~min}$.

Data analysis is performed using the Tofware package (version 3.1.0) running in the Igor Pro (WaveMetrics, OR, USA) environment. Time-of-flight values were converted to mass-to-charge ratios in the I-CIMS data using a calibration 
curve based on the times for $\mathrm{I}^{-}, \mathrm{I}_{2} \mathrm{H}_{2} \mathrm{O}^{-}$and $\mathrm{I}_{3}^{-}$. The instrument was operated at a $\sim 4000 \mathrm{Th} \mathrm{Th}^{-1}$ resolving power. Further analysis was carried out in custom Python 3 procedures using the pandas, Matplotlib and NumPy packages.

While the FIGAERO is capable of providing information about both gas and particle phases, the gas-phase I-CIMS spectra obtained during the medium- $\mathrm{NO}_{x}$ experiments were complicated by the presence of high nitric acid formed in the OFR from the $\mathrm{N}_{2} \mathrm{O}$ precursor (Lambe et al., 2017; Peng et al., 2018). High nitric acid depletes the $\mathrm{I}^{-}$reagent ion to form $\mathrm{NO}_{3}^{-}$, which subsequently acts as an additional reagent ion and complicates interpretation of the observed CIMS spectra. Thus, the gas-phase measurements are deemed unsuitable for the comparison of medium- and low- $\mathrm{NO}_{x}$ conditions, and the high-resolution analysis of the I-CIMS spectra was only carried out for the particle-phase FIGAERO data. These data provide thermal desorption profiles that have been previously used to draw conclusions about the volatility distribution of ions. However, we do not make use of this in this study owing to the additional complexity associated with the calibration of the volatility and uncertainties with thermal decomposition (Bannan et al., 2019; Schobesberger et al., 2018; Stark et al., 2017); instead, we integrate these desorption profiles in order to compare the overall composition of the different precursors. For all plant and VOC experiments, $>70 \%$ of observed product signal was assigned with molecular formulae, and these ions are used for analysis in the following.

Quantification of highly oxidised species measured by ICIMS is challenging due to the lack of available standards for many of the observed products. Previous attempts at quantification have used functional group dependencies, collision limit sensitivities or sensitivities derived from ion-adduct declustering scans (Lopez-Hilfiker et al., 2016). Experimental limitations exist in the use of these techniques, meaning that quantification remains a challenge (Riva et al., 2019); thus, in this study, we utilise observed ion signal intensities without accounting for species-dependent differences in instrument sensitivity. Iodide is more sensitive to oxidised organic species and, thus, is likely to overestimate the relative contribution of the more oxidised compounds and underestimate the relative contribution of the less oxidised compounds to SOA. However, given that the comparison here is between VOC and oxidant systems that yield similar products, we expect that these sensitivity differences will not influence the relative contributions of different compounds classes, although estimates of absolute contributions may be an upper bound.

\subsection{TD-GC-FID-ToF-MS VOC measurements}

Gas-phase VOC profiles observed during the SOA experiments using real plants were characterised at the inlet of the PAM flow reactor. Samples were collected by trapping VOCs onto multi-bed adsorbent cartridges containing Carbograph 5TD and Tenax TA adsorbents (Markes International, part no. C2-AXXX-5149). Sampling lines were conditioned for a minimum of $10 \mathrm{~min}$ to minimise VOC line losses before attaching adsorbent cartridges. Air was pulled through duplicate cartridges with a sampling pump at $300 \mathrm{~cm}^{3} \mathrm{~min}^{-1}$ for $20 \mathrm{~min}$. On days when experiments were run using real plant emissions, duplicate cartridges were collected at the PAM inlet at least twice per day. Cartridges were shipped overnight to University of California, Irvine on ice for offline analysis on a thermal-desorption gas chromatograph interfaced with a flame ionisation detector and a time-of-flight mass spectrometer (TD-GC-ToF-MS: TD-Series 2 UNITY + ULTRA, Markes International; 7890B Agilent GC-FID; BenchTOFSelect MS, Markes International). Compounds were identified using the $70 \mathrm{eV}$ MS spectra by comparing them with compounds in the National Institute of Standards and Technology (NIST) library. Terpene mixing ratios at the PAM inlet were quantified with the FID signal as described elsewhere using the effective carbon-number concept (Faiola et al., 2012).

\subsection{AMS measurements}

SOA composition was continuously measured at the PAM outlet with a high-resolution long-time-of-flight aerosol mass spectrometer (HR-LToF-AMS; Aerodyne Research, Inc.), which is described in detail elsewhere (Canagaratna et al., 2007; DeCarlo et al., 2006). Briefly, the HR-LToF-AMS collimates submicron particles into a narrow beam with an aerodynamic lens. The particle beam is directed onto a vaporiser plate at $600{ }^{\circ} \mathrm{C}$ to vaporise non-refractory components. Volatilised fragments are ionised with $70 \mathrm{eV}$ electron impact ionisation and detected with a long-ToF mass spectrometer (Tofwerk, resolving power $4000 \mathrm{Th} \mathrm{Th}^{-1}$ ) where the ionised fragments are separated by mass. The detection efficiency was calibrated with monodisperse ammonium nitrate particles generated with a constant output atomiser (TSI, Model 3076) and a differential mobility analyser (DMA, TSI, Model 3080). AMS data were analysed using the Squirrel (v1.60P) and Pika (v1.20P) ToF-AMS toolkits in Igor Pro (v6.37; WaveMetrics, Inc.). Medium- $\mathrm{NO}_{x}$ experiments had a large $\mathrm{N}_{2} \mathrm{O}$ interference with $\mathrm{CO}_{2}$; thus, $\mathrm{O} / \mathrm{C}$ values are not presented.

\subsection{Summary of experiments}

During this study, the VOC mixing ratios were measured for the plant mixture experiments by TD-GC-FID-ToF-MS and ranged from 27 to $34 \mathrm{ppb}$ (as shown in Table 2), with approximately $80 \%$ by mass from oxygenated monoterpenes. Of the single-component experiments, VOC mixing ratios were estimated to be $115 \mathrm{ppb}$ for eucalyptol via its injection rate through the syringe pump, whereas camphor and camphene could not be estimated using this approach due to their introduction via sublimation. Thus, VOC mixing ratios for camphor were estimated to be $61 \mathrm{ppb}$ on the basis of the SOA 
mass yield from the plants, which under low-NO, no-seed conditions was approximately $8 \%$ for mass loadings ranging from 4 to $19 \mu \mathrm{g} \mathrm{m}^{-3}$, similar to that for other monoterpenes such as $\alpha$-pinene (Donahue et al., 2012; Shilling et al., 2008). An $8 \%$ yield from eucalyptol would correspond to an estimated $130 \mathrm{ppb}$ at the inlet, which is similar to the $115 \mathrm{ppb}$ calculated based on the syringe pump injection rate and dilution. For camphene, the VOC mixing ratios are estimated to be $30 \mathrm{ppb}$, based on a reported yield from $\beta$-pinene from PAM-OFR experiments (Friedman and Farmer, 2018). Calculations of remaining VOC for the single-component experiments show that all VOCs are reacted under the $\mathrm{OH}$ exposures employed in this study, thereby validating the use of the aerosol yield itself to estimate VOC concentrations.

A summary of the measured and estimated VOC concentrations are included in Table 2 as well as aerosol mass concentrations, $\mathrm{OH}$ exposures, modelled $\mathrm{NO}_{x}$ conditions, $\mathrm{VOC} / \mathrm{OH}$ and $\mathrm{VOC} / \mathrm{NO}_{x}$ ratios. The "OH exposure with VOCs" accounts for reductions in $\mathrm{OH}$ exposure following additions of VOCs (Li et al., 2015). The intervals presented in Table 2 represents aerosol that was collected over a period of 20-30 min after aerosol mass concentrations stabilised; thus, each setting represents an integrated average that was analysed as a single mass spectrum. One averaging interval was used to characterise the aerosol composition for each VOC system under low- and medium- $\mathrm{NO}_{x}$ conditions.

\section{Results and discussion}

\subsection{VOC emissions from plants}

Figure 1 shows a single snapshot of the VOC composition from these plants, measured by TD-GC-FID-ToF-MS, to note the main features relevant for the SOA composition measured with I-CIMS. Both Sage and Artemisia plant emission profiles are dominated by oxygenated monoterpenes ( $72 \%$ and $79 \%$ respectively), which is the least studied BVOC type (Goldstein and Galbally, 2007), while other monoterpenes have a small contribution $(20 \%$ and $13 \%$ respectively). For Artemisia, eucalyptol contributes a larger proportion of the signal than camphor $(25 \%$ and $5 \%$ respectively), whereas camphor alone dominates the emission profile of Sage $(57 \%)$. Artemisia has a large contribution (49\%) from other oxygenated monoterpene species. The speciation of VOC emissions varies between the two plants, and the detailed VOC profiles and SOA yields will be presented in a separate paper. Of the monoterpenes, the composition of SOA from camphene is least well characterised due to its low reactivity with ozone; however, it is highly reactive with hydroxyl radical (Gaona-Colmán et al., 2017) and is, therefore, studied in detail in this paper. The following section focuses on the characterisation and comparison of SOA from the photooxidation of camphor, camphene and eucalyptol alongside SOA produced from the photooxidation of the
Sage and Artemisia plant emissions under low- and medium$\mathrm{NO}_{x}$ conditions.

\subsection{Overview of SOA composition}

Here, we utilise the ions identified in each experiment to carry out a qualitative comparison of the SOA composition between the different VOC precursors and plants. Figure $2 \mathrm{a}$ shows a Venn diagram of the number of distinct molecular formulas used in the high-resolution ion peak lists for camphene, camphor and eucalyptol spectra. A majority of the assigned ions are unique to each of the precursors, and a small number of ions are non-unique (i.e. are present in the mass spectra of all three of the precursors). The relatively small number of non-unique ions (39) formed from all of the precursors contributes to $>70 \%$ of the product signal observed (Fig. 2b). The unique ion signal is minor and is distributed across many more ions (80-437; Fig. 2a). Due to the relatively low signal intensity of these individual unique ions, it is not deemed suitable to use them as markers, particularly as there is ambiguity in their assignment under the limited resolution of the mass spectrometer and potential artefacts due to thermal decomposition caused by the FIGAERO. The percentage of signal from the 20 highest intensity ions (Fig. 3) shows that the complexity of SOA from plants is greater than that of single components, as up to $40 \%-60 \%$ of the product signal can be attributed to the top 20 ions. The top 20 ions observed under low- and medium- $\mathrm{NO}_{x}$ conditions are listed in Tables S1 and S2 in the Supplement respectively.

\subsection{HOM and oligomer formation}

Figure 4 plots the ions observed during all experiments according to their carbon and oxygen numbers. This figure highlights some of the differences in the SOA spectra between the single precursors and the plant emissions. Oxidation of camphene yields mainly small, low mass (Fig. S1), molecular fragmentation products $\left(<\mathrm{C}_{10}\right)$ as compared with camphor and eucalyptol which have many more products at higher carbon numbers. The bulk of the signal for camphene SOA is spread amongst fragmentation products, whereas for camphor it is a mixture between fragmentation and those retaining the carbon backbone of the precursor (Fig. 2, vertical black line). The presence of oxidised fragmentation products in the case of camphene potentially shows that there is an increased prevalence of fragmentation pathways during the oxidation of camphene, whereas the oxidation of camphor and eucalyptol proceed via pathways that retain their carbon backbone more readily. In eucalyptol SOA, for example, a large proportion of the signal can be attributed to oxidised $\mathrm{C}_{10}$ products which form with no fragmentation of the carbon backbone, and there is a larger contribution from oligomers $\left(\geq \mathrm{C}_{11}\right)$. 
Table 2. Summary of experimental conditions, where the VOC mixing ratios denoted by a are measured by TD-GC-FID-ToF-MS, those denoted by ${ }^{\mathrm{b}}$ are estimated from syringe pump injection, those denoted by ${ }^{\mathrm{c}}$ are estimated from SOA yields of $\beta$-pinene and those denoted by ${ }^{\mathrm{d}}$ are estimated from SOA yields of plant experiments.

\begin{tabular}{|c|c|c|c|c|c|c|c|c|c|}
\hline \multirow[t]{3}{*}{ Precursor } & \multirow{3}{*}{$\begin{array}{l}\mathrm{NO}_{x} \\
\text { condition }\end{array}$} & \multirow{3}{*}{$\begin{array}{l}\text { VOC mixing } \\
\text { ratios (ppb) }\end{array}$} & \multirow{3}{*}{$\begin{array}{r}\text { AMS aerosol mass } \\
\text { concentrations } \\
\left(\mu \mathrm{g} \mathrm{m}^{-3}\right)\end{array}$} & \multicolumn{2}{|c|}{$\mathrm{OH}$ exposure } & \multirow{3}{*}{$\begin{array}{r}\mathrm{NO} \\
(\mathrm{ppb})\end{array}$} & \multirow{3}{*}{$\begin{array}{l}\mathrm{NO}_{2} \\
(\mathrm{ppb})\end{array}$} & \multirow[t]{3}{*}{$\mathrm{VOC} / \mathrm{OH}$} & \multirow[t]{3}{*}{$\mathrm{VOC} / \mathrm{NO}_{x}$} \\
\hline & & & & with VOCs & without VOCs & & & & \\
\hline & & & & \multicolumn{2}{|c|}{$\left(\times 10^{11}\right.$ molec $\left.\mathrm{cm}^{-3}\right)$} & & & & \\
\hline \multirow[t]{2}{*}{ Artemisia } & Low & $27^{a}$ & 9.35 & 10.02 & - & 0 & 0 & 48.7 & \\
\hline & Med & $28^{\mathrm{a}}$ & - & 5.29 & - & 2.1 & 51.8 & 97.7 & 0.52 \\
\hline \multirow[t]{2}{*}{ Sage } & Low & $28^{\mathrm{a}}$ & 18 & 7.32 & - & 0 & 0 & 70.6 & \\
\hline & Med & $34^{\mathrm{a}}$ & - & 4.09 & - & 1.7 & 48.5 & 154 & 0.68 \\
\hline \multirow[t]{2}{*}{ Camphene } & Low & $30^{\mathrm{c}}$ & 20 & 10.14 & 10.1 & 0 & 0 & 48.7 & \\
\hline & Med & & - & 4.57 & 4.16 & 2.2 & 58.4 & 121 & 0.49 \\
\hline \multirow[t]{2}{*}{ Camphor } & Low & $61^{\mathrm{d}}$ & 30 & 9.33 & 8.58 & 0 & 0 & 121 & \\
\hline & Med & & - & 4.67 & 3.77 & 2.2 & 57.0 & 241 & 1.03 \\
\hline \multirow[t]{2}{*}{ Eucalyptol } & Low & $115^{\mathrm{b}}$ & 66 & 7.16 & 5.51 & 0 & 0 & 296 & \\
\hline & Med & & - & 3.54 & 2.11 & 1.9 & 57.9 & 600 & 1.93 \\
\hline
\end{tabular}

(a) Sage

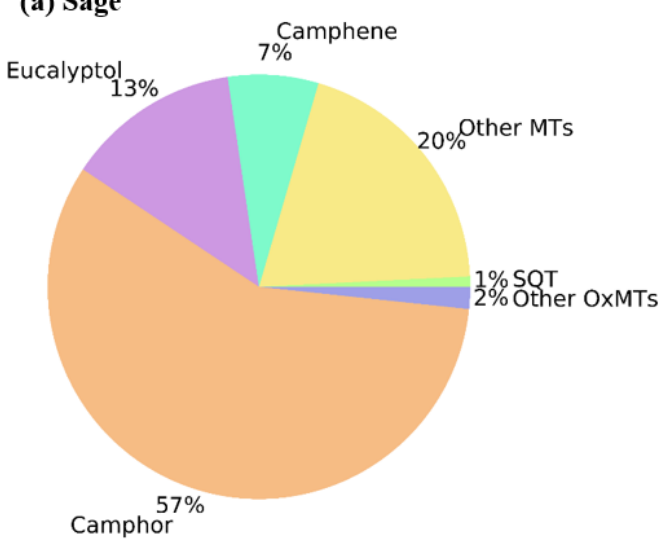

(b) Artemisia

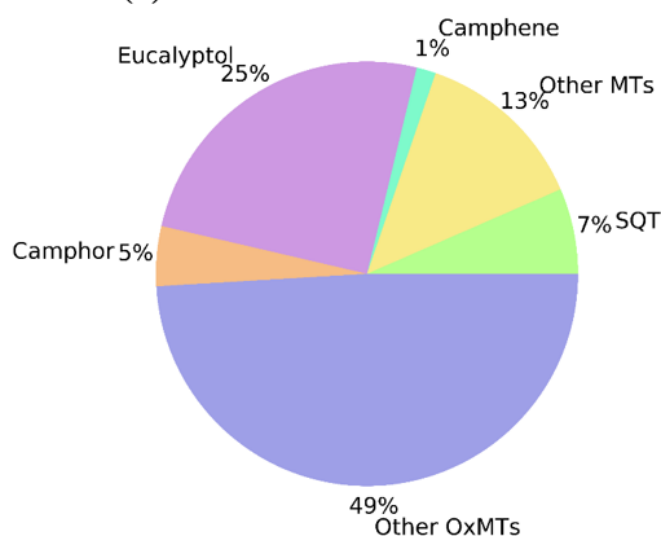

Figure 1. Volatile organic compound emission profiles of (a) Sage and (b) Artemisia where OxMTs are oxygenated monoterpenes, MTs are monoterpenes and SQT are sesquiterpenes.

Despite different species contributing to the emissions profiles for the two plants, the bulk composition and average molecular formulas are similar (Table 3). A potential explanation for this is the similar contributions from oxygenated monoterpenes (Fig. 1), which may have similar SOA characteristics despite different speciation. The monomer region of plant SOA $\left(\leq \mathrm{C}_{10}\right)$ can be attributed to fragmentation products from all VOCs. However, the presence of oligomers $\left(\geq \mathrm{C}_{11}\right)$ in the plant SOA is likely to be from products associated with the oxygenated monoterpenes, as camphene shows few oligomer products (Fig. 4).

Table 3 shows the average $\mathrm{O} / \mathrm{C}$ of I-CIMS calculated by averaging across molecular formulas as well as the bulk $\mathrm{O} / \mathrm{C}$ determined from AMS for the low- $\mathrm{NO}_{x}$ conditions. The average molecular formulas for each condition, obtained by averaging over the distributions for each element, are also shown. Table 3 indicates that increasing $\mathrm{NO}_{x}$ results in a slight increase in $\mathrm{O} / \mathrm{C}$ across most of the systems. The average molecular formulas indicate that this increase is caused by both a slight decrease in the average $\mathrm{C}$ number and an increase in the average $\mathrm{O}$ number. Fewer high-carbon-number products are observed under medium- $\mathrm{NO}_{x}$ conditions for all precursors; however, this effect is more notable in the singlecomponent experiments than in the plant SOA, where lowand medium- $\mathrm{NO}_{x}$ conditions look largely similar (Fig. 4). Under medium- $\mathrm{NO}_{x}$ conditions, nitrogen-containing prod- 

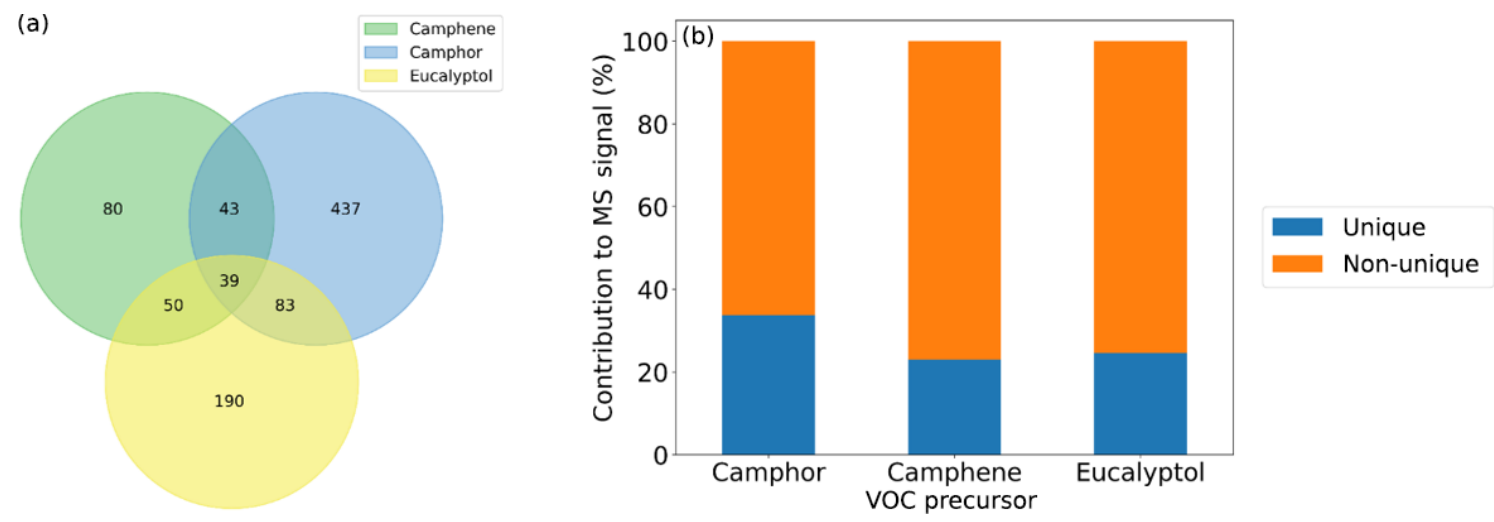

Figure 2. (a) Comparison of ions from peak lists of individual volatile organic compound precursors (number of ions shown in Venn diagram). (b) The contribution of unique and non-unique products to the total signal derived from the Venn diagram under low- $\mathrm{NO}_{x}$ conditions.

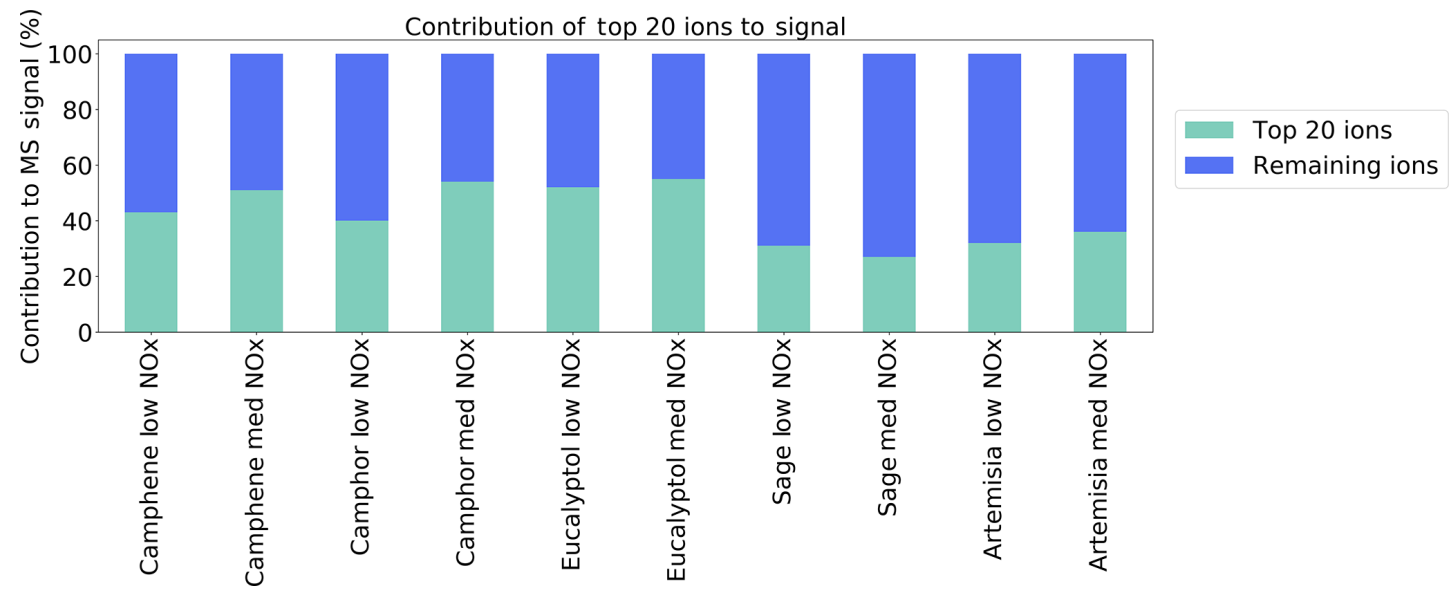

Figure 3. Contribution of the top 20 ions to observed product signal.

ucts are observed, with the largest contributions to the signal in camphor (35\%), followed by Sage (30\%), camphene $(28 \%)$, Artemisia (19\%) and eucalyptol (7\%).

Two key pathways of SOA formation from BVOCs have been identified: the formation of highly oxygenated organic molecules (HOM) (Bianchi et al., 2019; Ehn et al., 2014; Jokinen et al., 2014; Tu et al., 2016) and oligomerisation (Hall and Johnston, 2011; Kourtchev et al., 2016; Kundu et al., 2012; Putman et al., 2011; Tolocka et al., 2004). HOMs are defined here as ions that contain six or more oxygen atoms (Bianchi et al., 2019). Figure 5 shows the relative contributions of HOM and oligomer products to the observed signal for the different precursors and plants, aiding in the evaluation of the relative importance of different SOA formation pathways under low- and medium- $\mathrm{NO}_{x}$ conditions. The products detected by I-CIMS are typically multifunctional oxidised species, which do not fully represent the SOA formed from a given system. Thus, the I-CIMS signal represents only a portion of the SOA, and the reported contributions of this portion are likely to be an upper bound of the contribution of oligomers and HOM to the total SOA. This study aims to compare the relative contributions of different SOA components across the different single-precursor and plant experiments rather than quantifying the absolute contributions of any of the components. Owing to the similarity in composition across these systems, we expect that the ratios described here are not significantly affected by uncertainties in quantification.

Our results show the large contributions of HOMs to the total product signal from the oxygenated monoterpenes of up to $40 \%$, whereas the contributions of HOMs to camphene SOA are as low as $12 \%-14 \%$ (Fig. 5). HOMs show minimal differences in their contribution to the signal between low- and medium- $\mathrm{NO}_{x}$ conditions, whereas oligomers show a decrease in all cases with $\mathrm{NO}_{x}$ addition. This suggests that HOM formation itself, a rapid intramolecular process, is not hindered by $\mathrm{NO}_{x}$ under these conditions, whereas NO hinders oligomerisation. Figure 5 also indicates that the oligomer content in SOA is highest for oxygenated monoterpenes. Previous studies of mixtures have shown the oligomer content to be similar to that of $\alpha$-pinene alone (Kourtchev et al., 2016). However, our results suggest that in plant species 


\section{SOA from VOCs}
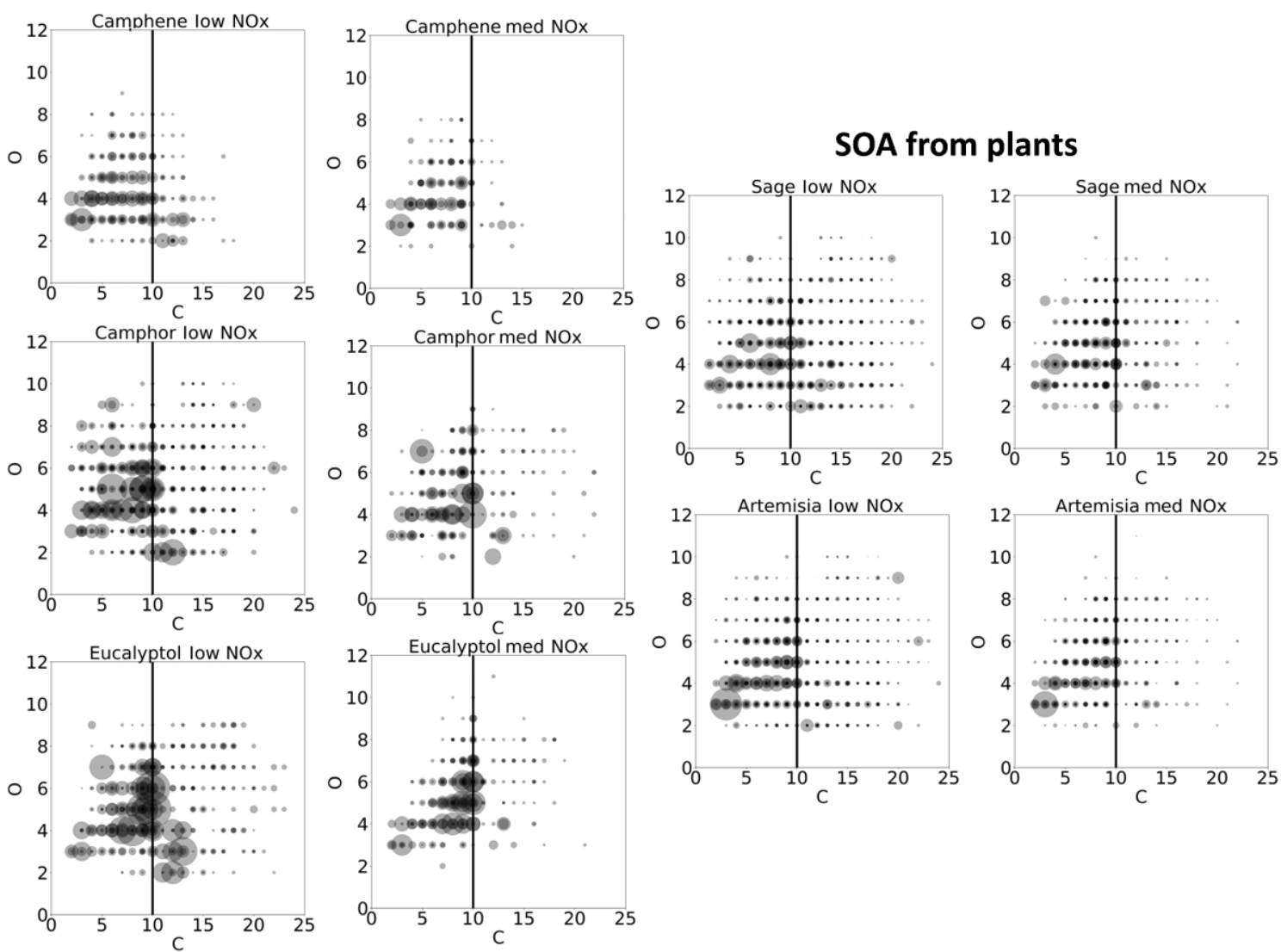

Figure 4. Carbon vs. oxygen plot for aerosol-phase composition under low- and medium- $\mathrm{NO}_{x}$ conditions for volatile organic compound precursors and plants. (The vertical black line separates monomers and oligomers in carbon-number space, and the symbols are proportional to the ion intensity.)

Table 3. Bulk composition of secondary organic aerosol from single-component standards and plants.

\begin{tabular}{llrrl}
\hline Precursor & Condition & O/C I-CIMS & O/C AMS & $\mathrm{C}_{X} \mathrm{H}_{Y} \mathrm{O}_{Z}$ \\
\hline Camphene & Low $\mathrm{NO}_{x}$ & 0.69 & 0.70 & $\mathrm{C}_{7.26} \mathrm{H}_{9.85} \mathrm{O}_{4.03}$ \\
& Medium $\mathrm{NO}_{x}$ & 0.74 & - & $\mathrm{C}_{6.63} \mathrm{H}_{9.7} \mathrm{~N}_{0.12} \mathrm{O}_{4.21}$ \\
\hline \multirow{2}{*}{ Camphor } & Low $\mathrm{NO}_{x}$ & 0.66 & 0.64 & $\mathrm{C}_{8.97} \mathrm{H}_{12.34} \mathrm{O}_{4.8}$ \\
& Medium $\mathrm{NO}_{x}$ & 0.66 & - & $\mathrm{C}_{8.34} \mathrm{H}_{11.98} \mathrm{~N}_{0.07} \mathrm{O}_{4.71}$ \\
\hline \multirow{2}{*}{ Eucalyptol } & Low $\mathrm{NO}_{x}$ & 0.58 & 0.52 & $\mathrm{C}_{9.45} \mathrm{H}_{13.09} \mathrm{O}_{4.85}$ \\
& Medium $\mathrm{NO}_{x}$ & 0.65 & - & $\mathrm{C}_{8.47} \mathrm{H}_{12.37} \mathrm{~N}_{0.01} \mathrm{O}_{5.06}$ \\
\hline \multirow{2}{*}{ Sage } & Low $\mathrm{NO}_{x}$ & 0.74 & 0.78 & $\mathrm{C}_{9.54} \mathrm{H}_{13.30} \mathrm{O}_{4.52}$ \\
& Medium $\mathrm{NO}_{x}$ & 0.66 & - & $\mathrm{C}_{8.42} \mathrm{H}_{12.34} \mathrm{~N}_{0.09} \mathrm{O}_{4.66}$ \\
\hline \multirow{2}{*}{ Artemisia } & Low $\mathrm{NO}_{x}$ & 0.67 & 0.74 & $\mathrm{C}_{8.51} \mathrm{H}_{11.79} \mathrm{O}_{4.58}$ \\
& Medium $\mathrm{NO}_{x}$ & 0.71 & - & $\mathrm{C}_{7.62} \mathrm{H}_{11.07} \mathrm{~N}_{0.06} \mathrm{O}_{4.65}$ \\
& & & &
\end{tabular}

which emit low amounts of $\alpha$-pinene, such as Sage and Artemisia, other VOCs such as camphor and eucalyptol may become important for oligomer formation. It should be noted that VOC concentrations were higher in the case of eucalyptol compared with the other single-component and plant stud- ies, and this could influence the extent to which oligomers contribute to SOA (Kourtchev et al., 2016). However, the estimated VOC mixing ratios for the other single-component and plant experiments were more similar to one another. Furthermore, the oligomer content observed in the plant exper- 

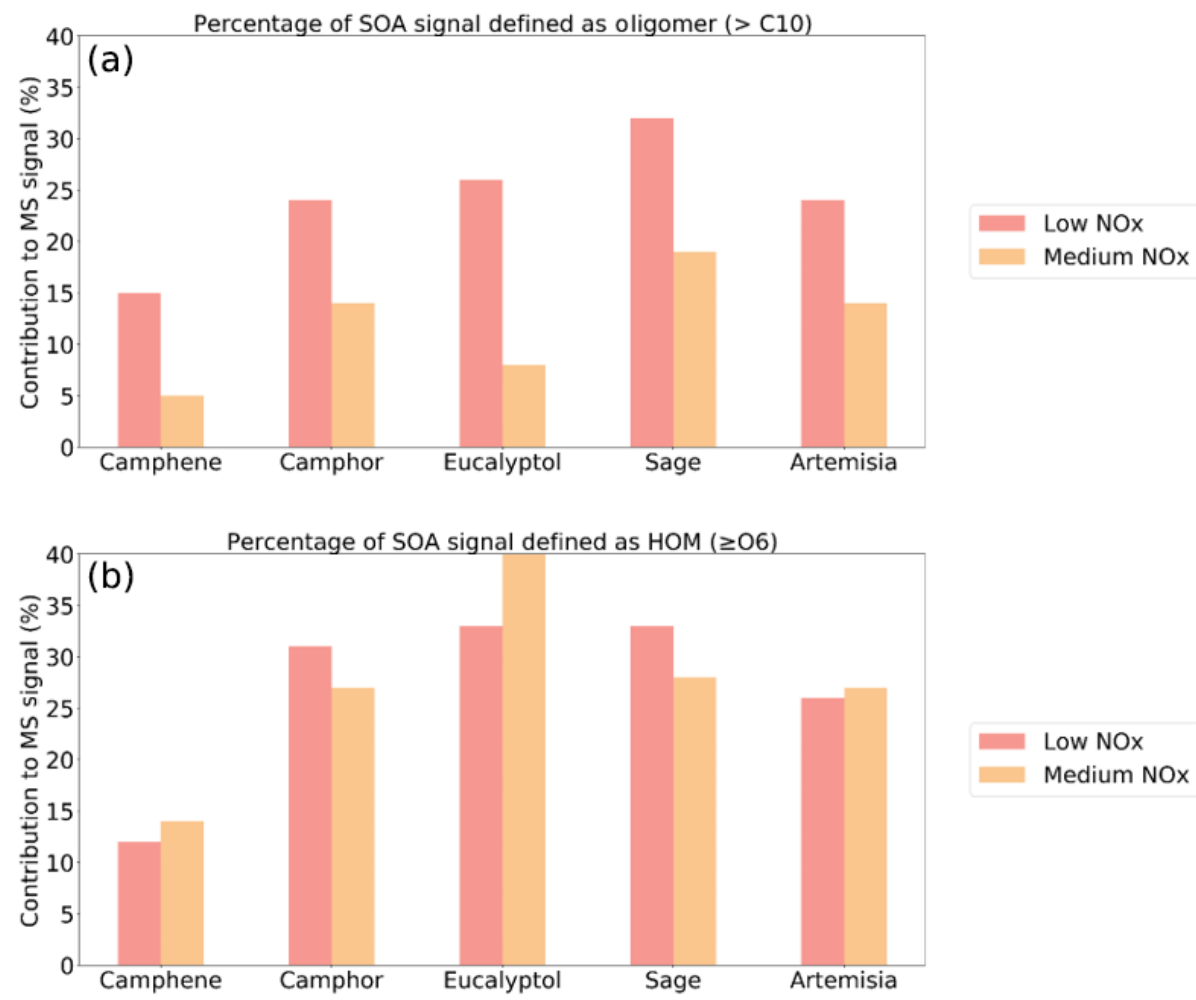

Figure 5. Comparison of the proportion of the signal attributable to oligomeric species (a) and highly oxygenated organic molecules (b).

iments, which had lower VOC mixing ratios than that of the single-component experiments, are comparable to that of camphor.

\section{Conclusions and implications}

Emissions of VOCs from Sage and Artemisia plants, which are widespread in California and much of the western United States, are different from those of other commonly studied plants such as conifers and broad-leaved trees, as emissions of oxygenated monoterpenes are the largest fraction. Here, we have presented a detailed chemical characterisation of SOA from Sage and Artemisia plants, from two oxygenated monoterpene precursors emitted by these species (camphor and eucalyptol) and from a monoterpene (camphene). Results show that up to $40 \%$ of the product signal was from HOMs for the oxygenated monoterpene precursors and that clear oligomerisation was observed. Under elevated $\mathrm{NO}_{x}$ conditions, $\mathrm{HOM}$ formation did not change significantly. However, oligomerisation was reduced for all precursors and plants.

This study shows that HOM and oligomer formation is potentially important for SOA formed from the oxidation of oxygenated monoterpenes. These compounds are commonly emitted by woody shrubs, but they have not been the subject of previous SOA studies. Owing to the potential of these VOCs to form HOM and oligomer products, future labora- tory studies should encompass a broader range of $\mathrm{VOC} / \mathrm{OH}$ and $\mathrm{VOC} / \mathrm{NO}_{x}$ ratios, due to the potential influence this has on the proportion of oligomers formed (Kourtchev et al., 2016), alongside seed acidity and humidity dependence. In addition, there are uncertainties pertaining to the absolute contributions of HOM and oligomer products to the SOA from these plant and precursor systems owing to challenges calibrating for these oxidised products for which no standards exist. These uncertainties may influence the absolute magnitude of the contributions of these compound classes to SOA. This study provides insights into the SOA formation from VOC systems not previously studied with respect to their SOA formation potential, and these results should be taken as a basis upon which to study their potential importance for ambient SOA formation in more detail.

Sage plants emit a mixture of BVOCs, and SOA formed from their emissions shows greater complexity than single components, although the majority of ions observed are generic monoterpene oxidation products emitted from all of the investigated VOCs. Thus, constraining VOC contributions to SOA in complex mixtures remains a challenge. Our results clearly show that HOMs can contribute up to $33 \%$ of the signal in the plant emission mixtures and oligomerisation continues to be a significant fraction of the SOA. This indicates that oxygenated monoterpenes may be key to understanding SOA in regions with many Sage plants or other high oxygenated monoterpene-emitting plant species. 
This is the first detailed study of oxygenated monoterpene SOA chemistry using both single-component standards and real plant emissions. Eucalypts, which are dominant emitters of eucalyptol, are present globally, comprise many different species and are likely globally important for SOA formation. Previously reported low thresholds of new particle formation from species containing high proportions of oxygenated monoterpenes (Mentel et al., 2009) could be explained by the high oligomer content of the SOA we observed for these VOCs and in the mixtures. High oligomer content has been shown to influence particle viscosity by intraand inter-molecular hydrogen bonding between oligomers (Huang et al., 2018); thus, our results could indicate very different physicochemical properties for SOA generated from plants that contain high proportions of oxygenated monoterpenes.

Data availability. Data are available upon request from the corresponding authors.

Supplement. The supplement related to this article is available online at: https://doi.org/10.5194/acp-20-10953-2020-supplement.

Author contributions. CF designed the experiments. Instrument deployment and operation were carried out by CF, AM, JEK, CS, LW and FK. Aerosol mass spectrometer analysis was carried out by $\mathrm{CF}$. AM carried out the analysis using the time-of-flight chemical ionisation mass spectrometer and wrote the paper. AG and CS ran the volatile sample analysis. All co-authors discussed the results and commented on the paper.

Competing interests. The authors declare that they have no conflict of interest.

Acknowledgements. Archit Mehra is fully funded by the Natural Environment Research Council (NERC) and acknowledges funding from a NERC EAO doctoral training partnership and an Aerodyne Research Inc. CASE partnership.

Financial support. This research has been supported by the Natural Environment Research Council (grant no. NE/L002469/1).

Review statement. This paper was edited by Alex Lee and reviewed by two anonymous referees.

\section{References}

Bannan, T. J., Le Breton, M., Priestley, M., Worrall, S. D., Bacak, A., Marsden, N. A., Mehra, A., Hammes, J., Hallquist, M., A1farra, M. R., Krieger, U. K., Reid, J. P., Jayne, J., Robinson, W., McFiggans, G., Coe, H., Percival, C. J., and Topping, D.: A method for extracting calibrated volatility information from the FIGAERO-HR-ToF-CIMS and its experimental application, Atmos. Meas. Tech., 12, 1429-1439, https://doi.org/10.5194/amt12-1429-2019, 2019.

Berndt, T., Richters, S., Jokinen, T., Hyttinen, N., Kurtén, T., Otkjaer, R. V, Kjaergaard, H. G., Stratmann, F., Herrmann, H., Sipilä, M., Kulmala, M., Ehn, M., Otkjær, R. V., Kjaergaard, H. G., Stratmann, F., Herrmann, H., Sipilä, M., Kulmala, M., and Ehn, M.: Hydroxyl radical-induced formation of highly oxidized organic compounds, Nat. Commun., 7, 13677, https://doi.org/10.1038/ncomms13677, 2016.

Bianchi, F., Kurtén, T., Riva, M., Mohr, C., Rissanen, M. P., Roldin, P., Berndt, T., Crounse, J. D., Wennberg, P. O., Mentel, T. F., Wildt, J., Junninen, H., Jokinen, T., Kulmala, M., Worsnop, D. R., Thornton, J. A., Donahue, N., Kjaergaard, H. G., and Ehn, M.: Highly Oxygenated Organic Molecules (HOM) from GasPhase Autoxidation Involving Peroxy Radicals: A Key Contributor to Atmospheric Aerosol, Chem. Rev., 119, 3472-3509, https://doi.org/10.1021/acs.chemrev.8b00395, 2019.

Carlton, A. G., Wiedinmyer, C., and Kroll, J. H.: A review of Secondary Organic Aerosol (SOA) formation from isoprene, Atmos. Chem. Phys., 9, 4987-5005, https://doi.org/10.5194/acp-9-49872009, 2009.

Carlton, A. G., Pye, H. O. T., Baker, K. R., and Hennigan, C. J.: Additional Benefits of Federal Air-Quality Rules: Model Estimates of Controllable Biogenic Secondary Organic Aerosol, Environ. Sci. Technol., 52, 9254-9265, https://doi.org/10.1021/acs.est.8b01869, 2018.

Ceacero-Vega, A. A., Ballesteros, B., Bejan, I., Barnes, I., Jimeìnez, E., and Albaladejo, J.: Kinetics and Mechanisms of the Tropospheric Reactions of Menthol, Borneol, Fenchol, Camphor, and Fenchone with Hydroxyl Radicals $(\mathrm{OH})$ and Chlorine Atoms (Cl), J. Phys. Chem. A, 116, 4097-4107, https://doi.org/10.1021/jp212076g, 2012.

Chung, S. H. and Seinfeld, J. H.: Global distribution and climate forcing of carbonaceous aerosols, J. Geophys. Res, 107, 4407, https://doi.org/10.1029/2001JD001397, 2002.

Claeys, M., Wang, W., Ion, A. C., Kourtchev, I., Gelencse, A., and Maenhaut, W.: Formation of secondary organic aerosols from isoprene and its gas-phase oxidation products through reaction with hydrogen peroxide, Atmos. Environ., 38, 4093-4098, https://doi.org/10.1016/j.atmosenv.2004.06.001, 2004.

Corchnoy, S. B. and Atkinson, R.: Kinetics of the gas-phase reactions of hydroxyl and nitrogen oxide $\left(\mathrm{NO}_{3}\right)$ radicals with 2carene, 1,8-cineole, p-cymene, and terpinolene, Environ. Sci. Technol., 24, 1497-1502, https://doi.org/10.1021/es00080a007, 1990.

DeCarlo, P. F., Kimmel, J. R., Trimborn, A., Northway, M. J., Jayne, J. T., Aiken, A. C., Gonin, M., Fuhrer, K., Horvath, T., Docherty, K. S., Worsnop, D. R., and Jimenez, J. L.: Field-deployable, high-resolution, time-of-flight aerosol mass spectrometer, Anal. Chem., 78, 8281-8289, https://doi.org/10.1021/ac061249n, 2006. 
Després, V. R., Huffman, A. J., Burrows, S. M., Hoose, C., Safatov, A. S., Buryak, G., Fröhlich-Nowoisky, J., Elbert, W., Andreae, M. O., Pöschl, U., and Jaenicke, R.: Primary biological aerosol particles in the atmosphere: A review, Tellus B, 64, 15598, https://doi.org/10.3402/tellusb.v64i0.15598, 2012.

Donahue, N. M., Kroll, J. H., Pandis, S. N., and Robinson, A. L.: A two-dimensional volatility basis set - Part 2: Diagnostics of organic-aerosol evolution, Atmos. Chem. Phys., 12, 615-634, https://doi.org/10.5194/acp-12-615-2012, 2012.

Dudareva, N., Negre, F., Nagegowda, D. A., and Orlova, I.: Plant volatiles: Recent advances and future perspectives, CRC. Crit. Rev. Plant Sci., 25, 417-440, https://doi.org/10.1080/07352680600899973, 2006.

Ehn, M., Thornton, J. A., Kleist, E., Sipilä, M., Junninen, H., Pullinen, I., Springer, M., Rubach, F., Tillmann, R., Lee, B., Lopez-Hilfiker, F., Andres, S., Acir, I. H., Rissanen, M., Jokinen, T., Schobesberger, S., Kangasluoma, J., Kontkanen, J., Nieminen, T., Kurtén, T., Nielsen, L. B., Jørgensen, S., Kjaergaard, H. G., Canagaratna, M., Dal Maso, M., Berndt, T., Petäjä, T., Wahner, A., Kerminen, V. M., Kulmala, M., Worsnop, D. R., Wildt, J., and Mentel, T. F.: A large source of lowvolatility secondary organic aerosol, Nature, 506, 476-479, https://doi.org/10.1038/Nature13032, 2014.

Faiola, C. L., Erickson, M. H., Fricaud, V. L., Jobson, B. T., and VanReken, T. M.: Quantification of biogenic volatile organic compounds with a flame ionization detector using the effective carbon number concept, Atmos. Meas. Tech., 5, 1911-1923, https://doi.org/10.5194/amt-5-1911-2012, 2012.

Faiola, C. L., Wen, M., and VanReken, T. M.: Chemical characterization of biogenic secondary organic aerosol generated from plant emissions under baseline and stressed conditions: inter- and intra-species variability for six coniferous species, Atmos. Chem. Phys., 15, 3629-3646, https://doi.org/10.5194/acp15-3629-2015, 2015.

Faiola, C. L., Buchholz, A., Kari, E., Yli-Pirilä, P., Holopainen, J. K., Kivimäenpää, M., Miettinen, P., Worsnop, D. R., Lehtinen, K. E. J., Guenther, A. B., and Virtanen, A.: Terpene Composition Complexity Controls Secondary Organic Aerosol Yields from Scots Pine Volatile Emissions, Nat. Sci. Rep., 8, 3053, https://doi.org/10.1038/s41598-018-21045-1, 2018.

Faiola, C. L., Pullinen, I., Buchholz, A., Khalaj, F., Ylisirniö, A., Kari, E., Miettinen, P., Holopainen, J. K., Kivimäenpää, M., Schobesberger, S., Yli-Juuti, T., and Virtanen, A.: Secondary Organic Aerosol Formation from Healthy and Aphid-Stressed Scots Pine Emissions, ACS Earth Space Chem., 3, 1756-1772, https://doi.org/10.1021/acsearthspacechem.9b00118, 2019.

Fiore, A. M., Naik, V., Spracklen, D. V, Steiner, A., Unger, N., Prather, M., Bergmann, D., Cameron-Smith, P. J., Cionni, I., Collins, W. J., Dalsøren, S., Eyring, V., Folberth, G. A., Ginoux, P., Horowitz, L. W., Josse, B., Lamarque, J.-F., Mackenzie, I. A., Nagashima, T., O 'connor, F. M., Righi, M., Rumbold, S. T., Shindell, D. T., Skeie, R. B., Sudo, K., Szopa, S., Takemura, T., and Zeng, G.: Global air quality and climate, Chem. Soc. Rev., 41, 6663-6683, https://doi.org/10.1039/c2cs35095e, 2012.

Forster, P., Ramaswamy, V., Artaxo, P., Berntsen, T., Betts, R., Fahey, D. W., Haywood, J., Lean, J., Lowe, D. C., Myhre, G., Nganga, J., Prinn, R., Raga, G., Schulz, M., and Van, R.: Changes in Atmospheric Constituents and in Radiative Forcing, in: Climate Change, IPCC, Geneva, Switzerland, 2007.
Friedman, B. and Farmer, D. K.: SOA and gas phase organic acid yields from the sequential photooxidation of seven monoterpenes, Atmos. Environ., 187, 335-345, https://doi.org/10.1016/j.atmosenv.2018.06.003, 2018.

Gaona-Colmán, E., Blanco, M. B., Barnes, I., Weisen, P., and Teruel, M. A.: $\mathrm{OH}-$ and $\mathrm{O}_{3}$-initiated atmospheric degradation of camphene: temperature dependent rate coefficients, product yields and mechanisms, RSC Adv., 7, 2733-2744, https://doi.org/10.1039/c6ra26656h, 2017.

Gentner, D. R., Ormeño, E., Fares, S., Ford, T. B., Weber, R., Park, J.-H., Brioude, J., Angevine, W. M., Karlik, J. F., and Goldstein, A. H.: Emissions of terpenoids, benzenoids, and other biogenic gas-phase organic compounds from agricultural crops and their potential implications for air quality, Atmos. Chem. Phys., 14, 5393-5413, https://doi.org/10.5194/acp-14-5393-2014, 2014.

Goldstein, A. H. and Galbally, I. E.: Known and unexplored organic constituents in the earth's atmosphere, Environ. Sci. Technol., 41, 1514-1521, https://doi.org/10.1021/es072476p, 2007.

Guenther, A.: Biological and Chemical Diversity of Biogenic Volatile Organic Emissions into the Atmosphere, ISRN Atmos. Sci., 2013, 786290, https://doi.org/10.1155/2013/786290, 2013.

Guenther, A., Hewitt, C. N., Erickson, D., Guenther, A., Hewitt, N. C., Erickson, D., Fall, R., Geron, C., Graedel, T., Harley, P., Klinger, L., Lerdau, M., Mckay, W. A., Pierce, T., Scholes, B., Steinbrecher, R., Tallamraju, R., Taylor, J., and Zimmerman, P.: A global model of natural volatile organic compound emissions, J. Geophys. Res., 100, 8873-8892, https://doi.org/10.1029/94JD02950, 1995.

Guenther, A. B., Jiang, X., Heald, C. L., Sakulyanontvittaya, T., Duhl, T., Emmons, L. K., and Wang, X.: The Model of Emissions of Gases and Aerosols from Nature version 2.1 (MEGAN2.1): an extended and updated framework for modeling biogenic emissions, Geosci. Model Dev., 5, 1471-1492, https://doi.org/10.5194/gmd-5-1471-2012, 2012.

Hall, W. A. and Johnston, M. V.: Oligomer Content of $\alpha$-Pinene Secondary Organic Aerosol, Aerosol Sci. Technol., 45, 37-45, https://doi.org/10.1080/02786826.2010.517580, 2011.

Hao, L. Q., Yli-Pirilä, P., Tiitta, P., Romakkaniemi, S., Vaattovaara, P., Kajos, M. K., Rinne, J., Heijari, J., Kortelainen, A., Miettinen, P., Kroll, J. H., Holopainen, J. K., Smith, J. N., Joutsensaari, J., Kulmala, M., Worsnop, D. R., and Laaksonen, A.: New particle formation from the oxidation of direct emissions of pine seedlings, Atmos. Chem. Phys., 9, 8121-8137, https://doi.org/10.5194/acp-9-8121-2009, 2009.

Hao, L. Q., Romakkaniemi, S., Yli-Pirilä, P., Joutsensaari, J., Kortelainen, A., Kroll, J. H., Miettinen, P., Vaattovaara, P., Tiitta, P., Jaatinen, A., Kajos, M. K., Holopainen, J. K., Heijari, J., Rinne, J., Kulmala, M., Worsnop, D. R., Smith, J. N., and Laaksonen, A.: Mass yields of secondary organic aerosols from the oxidation of $\alpha$-pinene and real plant emissions, Atmos. Chem. Phys., 11, 1367-1378, https://doi.org/10.5194/acp-11-1367-2011, 2011.

Hoffmann, T., Odum, J. R., Bowman, F., Collins, D., Klockow, D., Flagan, R. C., and Seinfeld, J. H.: Formation of Organic Aerosols from the Oxidation of Biogenic Hydrocarbons, J. Atmos. Chem., 26, 189-222, 1997.

Huang, W., Saathoff, H., Pajunoja, A., Shen, X., Naumann, K.H., Wagner, R., Virtanen, A., Leisner, T., and Mohr, C.: $\alpha$ Pinene secondary organic aerosol at low temperature: chemical composition and implications for particle viscosity, At- 
mos. Chem. Phys., 18, 2883-2898, https://doi.org/10.5194/acp18-2883-2018, 2018.

Jimenez, J. L., Canagaratna, M. R., Donahue, N. M., Prevot, A. S. H., Zhang, Q., Kroll, J. H., DeCarlo, P. F., Allan, J. D., Coe, H., Ng, N. L., Aiken, A. C., Docherty, K. S., Ulbrich, I. M., Grieshop, A. P., Robinson, A. L., Duplissy, J., Smith, J. D., Wilson, K. R., Lanz, V. A., Hueglin, C., Sun, Y. L., Tian, J., Laaksonen, A., Raatikainen, T., Rautiainen, J., Vaattovaara, P., Ehn, M., Kulmala, M., Tomlinson, J. M., Collins, D. R., Cubison, M. J., Dunlea, J., Huffman, J. A., Onasch, T. B., Alfarra, M. R., Williams, P. I., Bower, K., Kondo, Y., Schneider, J., Drewnick, F., Borrmann, S., Weimer, S., Demerjian, K., Salcedo, D., Cottrell, L., Griffin, R., Takami, A., Miyoshi, T., Hatakeyama, S., Shimono, A., Sun, J. Y., Zhang, Y. M., Dzepina, K., Kimmel, J. R., Sueper, D., Jayne, J. T., Herndon, S. C., Trimborn, A. M., Williams, L. R., Wood, E. C., Middlebrook, A. M., Kolb, C. E., Baltensperger, U., and Worsnop, D. R.: Evolution of Organic Aerosols in the Atmosphere, Science, 326, 1525-1529, https://doi.org/10.1126/science.1180353, 2009.

Jokinen, T., Sipilä, M., Richters, S., Kerminen, V. M., Paasonen, P., Stratmann, F., Worsnop, D., Kulmala, M., Ehn, M., Herrmann, H., and Berndt, T.: Rapid autoxidation forms highly oxidized $\mathrm{RO}_{2}$ radicals in the atmosphere, Angew. Chem. Int. Ed., 53, 14596-14600, https://doi.org/10.1002/anie.201408566, 2014.

Joutsensaari, J., Loivamäki, M., Vuorinen, T., Miettinen, P., Nerg, A.-M., Holopainen, J. K., and Laaksonen, A.: Nanoparticle formation by ozonolysis of inducible plant volatiles, Atmos. Chem. Phys., 5, 1489-1495, https://doi.org/10.5194/acp-5-1489-2005, 2005.

Joutsensaari, J., Yli-Pirilä, P., Korhonen, H., Arola, A., Blande, J. D., Heijari, J., Kivimäenpää, M., Mikkonen, S., Hao, L., Miettinen, P., Lyytikäinen-Saarenmaa, P., Faiola, C. L., Laaksonen, A., and Holopainen, J. K.: Biotic stress accelerates formation of climate-relevant aerosols in boreal forests, Atmos. Chem. Phys., 15, 12139-12157, https://doi.org/10.5194/acp-15-121392015, 2015.

Karban, R., Wetzel, W. C., Shiojiri, K., Ishizaki, S., Ramirez, S. R., and Blande, J. D.: Deciphering the language of plant communication: Volatile chemotypes of sagebrush, New Phytol., 204, 380-385, https://doi.org/10.1111/nph.12887, 2014.

Kourtchev, I., Giorio, C., Manninen, A., Wilson, E., Mahon, B., Aalto, J., Kajos, M., Venables, D., Ruuskanen, T., Levula, J., Loponen, M., Connors, S., Harris, N., Zhao, D., KiendlerScharr, A., Mentel, T., Rudich, Y., Hallquist, M., Doussin, J.F., Maenhaut, W., Bäck, J., Petäjä, T., Wenger, J., Kulmala, M., and Kalberer, M.: Enhanced Volatile Organic Compounds emissions and organic aerosol mass increase the oligomer content of atmospheric aerosols, Nat. Publ. Gr., 6, 35038, https://doi.org/10.1038/srep35038, 2016.

Kroll, J. H., Ng, N. L., Murphy, S. M., Flagan, R. C., and Seinfeld, J. H.: Secondary Organic Aerosol Formation from Isoprene Photooxidation, Environ. Sci. Technol., 40, 1869-1877, https://doi.org/10.1021/es0524301, 2006.

Kundu, S., Fisseha, R., Putman, A. L., Rahn, T. A., and Mazzoleni, L. R.: High molecular weight SOA formation during limonene ozonolysis: insights from ultrahigh-resolution FT-ICR mass spectrometry characterization, Atmos. Chem. Phys., 12, 5523-5536, https://doi.org/10.5194/acp-12-5523-2012, 2012.
Lamarque, J.-F., Bond, T. C., Eyring, V., Granier, C., Heil, A., Klimont, Z., Lee, D., Liousse, C., Mieville, A., Owen, B., Schultz, M. G., Shindell, D., Smith, S. J., Stehfest, E., Van Aardenne, J., Cooper, O. R., Kainuma, M., Mahowald, N., McConnell, J. R., Naik, V., Riahi, K., and van Vuuren, D. P.: Historical (1850-2000) gridded anthropogenic and biomass burning emissions of reactive gases and aerosols: methodology and application, Atmos. Chem. Phys., 10, 7017-7039, https://doi.org/10.5194/acp-10-7017-2010, 2010.

Lambe, A. T., Ahern, A. T., Williams, L. R., Slowik, J. G., Wong, J. P. S., Abbatt, J. P. D., Brune, W. H., Ng, N. L., Wright, J. P., Croasdale, D. R., Worsnop, D. R., Davidovits, P., and Onasch, T. B.: Characterization of aerosol photooxidation flow reactors: heterogeneous oxidation, secondary organic aerosol formation and cloud condensation nuclei activity measurements, Atmos. Meas. Tech., 4, 445-461, https://doi.org/10.5194/amt-4445-2011, 2011.

Lambe, A., Massoli, P., Zhang, X., Canagaratna, M., Nowak, J., Daube, C., Yan, C., Nie, W., Onasch, T., Jayne, J., Kolb, C., Davidovits, P., Worsnop, D., and Brune, W.: Controlled nitric oxide production via $\mathrm{O}\left({ }^{1} \mathrm{D}\right)+\mathrm{N}_{2} \mathrm{O}$ reactions for use in oxidation flow reactor studies, Atmos. Meas. Tech., 10, 2283-2298, https://doi.org/10.5194/amt-10-2283-2017, 2017.

Lee, B. H., Lopez-Hilfiker, F. D., Mohr, C., Kurtén, T., Worsnop, D. R., Thornton, J. A., Kurte, T., Worsnop, D. R., Thornton, J. A., Kurtén, T., Worsnop, D. R., and Thornton, J. A.: An iodide-adduct high-resolution time-of-flight chemical-ionization mass spectrometer: Application to atmospheric inorganic and organic compounds, Environ. Sci. Technol., 48, 6309-6317, https://doi.org/10.1021/es500362a, 2014.

Li, R., Palm, B. B., Ortega, A. M., Hlywiak, J., Hu, W., Peng, Z., Day, D. A., Knote, C., Brune, W. H., De Gouw, J. A., and Jimenez, J. L.: Modeling the Radical Chemistry in an Oxidation Flow Reactor: Radical Formation and Recycling, Sensitivities, and the $\mathrm{OH}$ Exposure Estimation Equation, J. Phys. Chem. A, 119, 4418-4432, https://doi.org/10.1021/jp509534k, 2015.

Lohmann, U. and Feichter, J.: Global indirect aerosol effects: a review, Atmos. Chem. Phys., 5, 715-737, https://doi.org/10.5194/acp-5-715-2005, 2005.

Lopez-Hilfiker, F. D., Mohr, C., Ehn, M., Rubach, F., Kleist, E., Wildt, J., Mentel, Th. F., Lutz, A., Hallquist, M., Worsnop, D., and Thornton, J. A.: A novel method for online analysis of gas and particle composition: description and evaluation of a Filter Inlet for Gases and AEROsols (FIGAERO), Atmos. Meas. Tech., 7, 983-1001, https://doi.org/10.5194/amt-7-983-2014, 2014.

Lopez-Hilfiker, F. D., Iyer, S., Mohr, C., Lee, B. H., D’Ambro, E. L., Kurtén, T., and Thornton, J. A.: Constraining the sensitivity of iodide adduct chemical ionization mass spectrometry to multifunctional organic molecules using the collision limit and thermodynamic stability of iodide ion adducts, Atmos. Meas. Tech., 9, 1505-1512, https://doi.org/10.5194/amt-9-1505-2016, 2016.

McFiggans, G., Mentel, T. F., Wildt, J., Pullinen, I., Kang, S., Kleist, E., Schmitt, S., Springer, M., Tillmann, R., Wu, C., Zhao, D., Hallquist, M., Faxon, C., Le Breton, M., Hallquist, A. M., Simpson, D., Bergström, R., Jenkin, M. E., Ehn, M., Thornton, J. A., Alfarra, M. R., Bannan, T. J., Percival, C. J., Priestley, M., Topping, D., and Kiendler-Scharr, A.: Secondary organic aerosol reduced by mixture of atmospheric vapours, Nature, 565, 587-593, https://doi.org/10.1038/s41586-018-0871-y, 2019. 
Mentel, Th. F., Wildt, J., Kiendler-Scharr, A., Kleist, E., Tillmann, R., Dal Maso, M., Fisseha, R., Hohaus, Th., Spahn, H., Uerlings, R., Wegener, R., Griffiths, P. T., Dinar, E., Rudich, Y., and Wahner, A.: Photochemical production of aerosols from real plant emissions, Atmos. Chem. Phys., 9, 4387-4406, https://doi.org/10.5194/acp-9-4387-2009, 2009.

Peng, Z., Day, D. A., Stark, H., Li, R., Lee-Taylor, J., Palm, B. B., Brune, W. H., and Jimenez, J. L.: HOx radical chemistry in oxidation flow reactors with low-pressure mercury lamps systematically examined by modeling, Atmos. Meas. Tech., 8, 4863-4890, https://doi.org/10.5194/amt-8-4863-2015, 2015.

Peng, Z., Palm, B. B., Day, D. A., Talukdar, R. K., Hu, W., Lambe, A. T., Brune, W. H., and Jimenez, J. L.: Model Evaluation of New Techniques for Maintaining High-NO Conditions in Oxidation Flow Reactors for the Study of $\mathrm{OH}$ Initiated Atmospheric Chemistry, ACS Earth Sp. Chem., 2, 7286, https://doi.org/10.1021/acsearthspacechem.7b00070, 2018.

Putman, A. L., Offenberg, J. H., Kundu, S., Rahn, T., Fisseha, R., Rahn, T. A., and Mazzoleni, L. R.: Ultrahighresolution FT-ICR mass spectrometry characterization of a-pinene ozonolysis SOA, Atmos. Enviro., 46, 164-172, https://doi.org/10.1016/j.atmosenv.2011.10.003, 2011.

Quéléver, L. L. J., Kristensen, K., Normann Jensen, L., Rosati, B., Teiwes, R., Daellenbach, K. R., Peräkylä, O., Roldin, P., Bossi, R., Pedersen, H. B., Glasius, M., Bilde, M., and Ehn, M.: Effect of temperature on the formation of highly oxygenated organic molecules (HOMs) from alpha-pinene ozonolysis, Atmos. Chem. Phys., 19, 7609-7625, https://doi.org/10.5194/acp19-7609-2019, 2019.

Riva, M., Rantala, P., Krechmer, J. E., Peräkylä, O., Zhang, Y., Heikkinen, L., Garmash, O., Yan, C., Kulmala, M., Worsnop, D., and Ehn, M.: Evaluating the performance of five different chemical ionization techniques for detecting gaseous oxygenated organic species, Atmos. Meas. Tech., 12, 2403-2421, https://doi.org/10.5194/amt-12-2403-2019, 2019.

Schobesberger, S., D’Ambro, E. L., Lopez-Hilfiker, F. D., Mohr, C., and Thornton, J. A.: A model framework to retrieve thermodynamic and kinetic properties of organic aerosol from composition-resolved thermal desorption measurements, Atmos. Chem. Phys., 18, 14757-14785, https://doi.org/10.5194/acp-1814757-2018, 2018

Shilling, J. E., Chen, Q., King, S. M., Rosenoern, T., Kroll, J. H., Worsnop, D. R., McKinney, K. A., and Martin, S. T.: Particle mass yield in secondary organic aerosol formed by the dark ozonolysis of $\alpha$-pinene, Atmos. Chem. Phys., 8, 2073-2088, https://doi.org/10.5194/acp-8-2073-2008, 2008.

Stark, H., Yatavelli, R. L. N., Thompson, S. L., Kang, H., Krechmer, J. E., Kimmel, J. R., Palm, B. B., Hu, W., Hayes, P. L., Day, D. A., Campuzano-Jost, P., Canagaratna, M. R., Jayne, J. T., Worsnop, D. R., and Jimenez, J. L.: Impact of Thermal Decomposition on Thermal Desorption Instruments: Advantage of Thermogram Analysis for Quantifying Volatility Distributions of Organic Species, Environ. Sci. Technol., 51, 8491-8500, https://doi.org/10.1021/acs.est.7b00160, 2017.
Tolocka, M. P., Jang, M., Ginter, J. M., Cox, F. J., Kamens, R. M., and Johnston, M. V.: Formation of Oligomers in Secondary Organic Aerosol, Environ. Sci. Technol., 38, 1428-1434, https://doi.org/10.1021/es035030r, 2004.

Tu, P., Hall, W. A., and Johnston, M. V.: Characterization of Highly Oxidized Molecules in Fresh and Aged Biogenic Secondary Organic Aerosol, Anal. Chem., 88, 4495-4501, https://doi.org/10.1021/acs.analchem.6b00378, 2016.

Tyson, B. J., Dement, W. A., and Mooney, H. A.: Volatilisation of terpenes from Salvia mellifera, Nature, 252, 119-121, https://doi.org/10.1038/252119a0, 1974.

VanReken, T. M., Greenberg, J. P., Harley, P. C., Guenther, A. B., and Smith, J. N.: Direct measurement of particle formation and growth from the oxidation of biogenic emissions, Atmos. Chem. Phys., 6, 4403-4413, https://doi.org/10.5194/acp-6-4403-2006, 2006.

Wyche, K. P., Ryan, A. C., Hewitt, C. N., Alfarra, M. R., McFiggans, G., Carr, T., Monks, P. S., Smallbone, K. L., Capes, G., Hamilton, J. F., Pugh, T. A. M., and MacKenzie, A. R.: Emissions of biogenic volatile organic compounds and subsequent photochemical production of secondary organic aerosol in mesocosm studies of temperate and tropical plant species, Atmos. Chem. Phys., 14, 12781-12801, https://doi.org/10.5194/acp-14-127812014, 2014.

Yli-Pirilä, P., Copolovici, L., Kännaste, A., Noe, S., Blande, J. D., Mikkonen, S., Klemola, T., Pulkkinen, J., Virtanen, A., Laaksonen, A., Joutsensaari, J., Niinemets, Ü., and Holopainen, J. K.: Herbivory by an Outbreaking Moth Increases Emissions of Biogenic Volatiles and Leads to Enhanced Secondary Organic Aerosol Formation Capacity, Environ. Sci. Technol., 50, 1150111510, https://doi.org/10.1021/acs.est.6b02800, 2016.

Ylisirniö, A., Buchholz, A., Mohr, C., Li, Z., Barreira, L., Lambe, A., Faiola, C., Kari, E., Yli-Juuti, T., Nizkorodov, S. A., Worsnop, D. R., Virtanen, A., and Schobesberger, S.: Composition and volatility of secondary organic aerosol (SOA) formed from oxidation of real tree emissions compared to simplified volatile organic compound (VOC) systems, Atmos. Chem. Phys., 20, 5629-5644, https://doi.org/10.5194/acp-205629-2020, 2020.

Zhang, X., Mcvay, R. C., Huang, D. D., Dalleska, N. F., Aumont, B., Flagan, R. C., and Seinfeld, J. H.: Formation and evolution of molecular products in $\alpha$-pinene secondary organic aerosol, P. Natl. Acad. Sci. USA, 112, 14168-14173, https://doi.org/10.1073/pnas.1517742112, 2015.

Zhao, D. F., Buchholz, A., Tillmann, R., Kleist, E., Wu, C., Rubach, F., Kiendler-Scharr, A., Rudich, Y., Wildt, J., and Mentel, T. F.: Environmental conditions regulate the impact of plants on cloud formation, Nat. Commun., 8, 1-8, https://doi.org/10.1038/ncomms14067, 2017. 